\title{
ADHESIVES WITH DIFFERENT PHS: EFFECT ON THE MTBS OF CHEMICALLY ACTIVATED AND LIGHT- ACTIVATED COMPOSITES TO HUMAN DENTIN
}

\author{
André MALLMANN ${ }^{1}$, Renata Marques de MELO ${ }^{2}$, Verbênia ESTRELA ${ }^{3}$, Fernanda PELOGIA ${ }^{2}$, \\ Laura CAMPOS 3 , Marco Antonio BOTTINO ${ }^{4}$, Luiz Felipe VALANDRO ${ }^{5}$
}

\author{
1- DDS, PhD, Associate Professor, School of Dentistry, Foundation for Science Development, Salvador, BA, Brazil. \\ 2- DDS, MSc, PhD Student, Dental School of São José dos Campos, São Paulo State University, São José dos Campos, SP, Brazil. \\ 3- DDS, Private Practice, Salvador, BA, Brazil. \\ 4- DDS, PhD, Chairman and Professor, Department of Dental Materials and Prosthodontics, Dental School of São José dos Campos, São \\ Paulo State University, São José dos Campos, SP, Brazil. \\ 5- DDS, MSc, PhD, Associate Professor, Division of Prosthodontics, Department of Restorative Dentistry, Federal University of Santa Maria, \\ RS, Brazil.
}

Corresponding address: Dra. Renata Marques de Melo, D.D.S, M.S. - FOSJC, Unesp, Departamento de Materiais Dentários e Prótese Avenida Engenheiro Fco José Longo 777, 12245-200, Jd. São Dimas - São José dos Campos-SP.

Phone:55 12 3947-9060 - e-mail: marquesdemelo@gmail.com

Received: June 20, 2006 - Modification: January 29, 2007 - Accepted: June 26, 2007

\begin{abstract}
$P$

urpose: To evaluate the bond strength between human dentin and composites, using two light-activated single-bottle total-etch adhesive systems with different pHs combined with chemically activated and light-activated-composites. The tested hypothesis was that the dentin bond strength is not influenced by an adhesive system of low pH, combined with chemically activated or light-activated composites. Material and Method: Flat dentin surfaces of twenty-eight human third molars were allocated in 4 groups $(n=7)$, depending on the adhesive system: (One Step Plus-OS and Prime \& Bond NT-PB) and composite (light-activated Filtek Z-100 [Z100] and chemically activated Bisfil 2B [B2B]). Each adhesive system was applied on acid-etched dentin and then one of the composites was added to form a $5 \mathrm{~mm}$-high resin block. The specimens were stored in tap water $\left(37^{\circ} \mathrm{C} / 24 \mathrm{~h}\right)$ and sectioned into two axes, $\mathrm{x}$ and $\mathrm{y}$. This was done with a diamond disk under coolant irrigation to obtain beams with a cross-section area of approximately $0.8 \mathrm{~mm}^{2}$. Each specimen was then attached to a custom-made device and submitted to the microtensile test $\left(1 \mathrm{~mm} \cdot \mathrm{min}^{-1}\right)$. Data were analyzed using two-way ANOVA and Tukey's tests $(\mathrm{p}<0.05)$. Results: The anticipated hypothesis was not confirmed $(\mathrm{p}<0.0001)$. The bond strengths $(\mathrm{MPa})$ were not statistically different between the two adhesive systems when light-activated composite was used $\left(O S+Z 100=24.7 \pm 7.1^{\mathrm{a}} ; \mathrm{PB}+\mathrm{Z} 100=23.8 \pm 5.7^{\mathrm{a}}\right)$. However, with use of the chemically activated composite (B2B), PB $\left(7.8 \pm 3.6^{\mathrm{b}} \mathrm{MPa}\right)$ showed significantly lower dentin bond strengths than OS $\left(32.2 \pm 7.6^{\mathrm{a}}\right)$. Conclusion: The low $\mathrm{pH}$ of the adhesive system can affect the bond of chemically activated composite to dentin. On the other hand, under the present conditions, the low $\mathrm{pH}$ did not seem to affect the bond of light-activated composites to dentin significantly.
\end{abstract}

Uniterms: Tensile-strength; Dentin-bonding agents; Composite resins.

\section{INTRODUCTION}

Changes in the concepts of cavity preparation have occurred as a result of the development of adhesive systems $^{8}$. Preparation of smaller cavities was rendered possible since Buonocore ${ }^{2}$ (1955) first established the basis of adhesive dentistry.

Contemporary dentin adhesive systems interact with the substrate by either removing the smear layer (etch and rinse approach) or modifying it for bonding (self-etch approach). However, bonding to dentin can be affected by a number of factors, such as type of dentin ${ }^{12,26}$, C-Factor ${ }^{3}, 15$, time of etching ${ }^{1}$, permeability of the adhesives after polymerization ${ }^{4,16,20}$ and, more recently, the incompatibility between adhesive systems and chemically or dual-activated resin materials $\mathrm{s}^{3,7,20,22,23,25}$.

Some studies have reported that the lower the $\mathrm{pH}$ of the adhesive, the lower the bond strength to dentin ${ }^{3,7,20,22}$. A correlation was observed between the decline in microtensile bond strengths of chemically activated composites coupled to bonded dentin and the acidity of these adhesives ${ }^{20}$. This phenomenon can be explained by an adverse acid-base reaction that occurs when chemically activated or dualactivated resins are placed in direct contact with the acidic 
monomer components of simplified adhesive systems (2step total-etch or 1-step self-etch). These monomers can react with the tertiary catalyst amines of the resin, thereby compromising its polymerization. Additionally, the reported decrease in the bond strength by using simplified adhesives would be due to hydrophilic features of these materials. When applied to a hydrated substrate, such as dentin, they showed to rapidly draw water from dentin ${ }^{22,25}$, resulting in delayed polymerization and/or hydrolysis of the interface $\mathrm{e}^{21,25,27}$.

Thus, the aim of this study was to evaluate the bond strengths between human dentin and composites, utilizing two light-activated single-bottle total-etch adhesive systems with different $\mathrm{pHs}$ combined with chemically activated and light-activated composites. The null tested hypothesis was that the $\mathrm{pH}$ of the adhesive system (informed by the manufacturer $)^{3,11,23}$ does not interfere with bond strengths produced by the chemically activated and light-activated composites to dentin.

\section{MATERIALAND METHOD}

Twenty-eight noncarious human molars were extracted for periodontal reasons, cleaned with periodontal scales and stored for less than 2 months in $0.5 \%$ chloramine. The teeth were collected after granting patients' informed consent.
The crowns were sectioned transversally with a diamond saw at low speed and copious water-cooling to expose midcoronal dentin. The roots were removed in the same manner at the cementoenamel junction. A standardized smear layer was created by wet-grounding flat the dentin surface with 600 -grit silicon carbide paper for $60 \mathrm{~s}$. The teeth were assigned to 4 groups ( $\mathrm{n}=7)$, according to the adhesive systems and the composite resins used (Table 1): G1: One Step adhesive system + light-activated Filtek Z-100 composite (3M ESPE, St Paul, MN, USA); G2: One Step adhesive system + chemically activated Bisfil 2B composite [B2B] (Bisco, Schaumburg, IL, USA); G3: Prime \& Bond NT + Z100; G4: Prime \& Bond NT + B2B.

The adhesives were applied according to the manufacturers' instructions (Table 1) and light-activated using a XL3000 (3M ESPE, operating at $600 \mathrm{~mW} / \mathrm{cm}^{2}$ ). Half of the teeth were chosen at random to be restored on an incremental basis with light-activated composite resin. Each increment (2 mm) was light-activated for $40 \mathrm{~s}$ (XL3000, 3M ESPE, operating at $600 \mathrm{~mW} / \mathrm{cm}^{2}$ ) until a $5 \mathrm{~mm}$-high resin block was formed. The chemically activated resin blocks were built by adding a single increment of $5 \mathrm{~mm}$ to the remaining dentin surfaces. The restored teeth were stored in distilled water for $24 \mathrm{~h}$ and then cut into two axes ( $\mathrm{x}$ and $\mathrm{y}$ ) with diamond disc under coolant irrigation in a cutting machine (LabCut 1010, Extec Corp., Enfied, CT, USA). This process resulted in non-trimmed beams (approximately 0.8

TABLE 1- Characteristics of adhesive systems and composites

\begin{tabular}{|c|c|c|c|c|c|}
\hline Materials & Manufacturer & Components & $\begin{array}{l}\text { Type of } \\
\text { polymerization }\end{array}$ & $\mathrm{pH}$ & $\begin{array}{l}\text { Application } \\
\text { mode* }\end{array}$ \\
\hline One Step (OS) & $\begin{array}{l}\text { Bisco, Schaumburg, } \\
\text { USA }\end{array}$ & $\begin{array}{l}\text { Bis-GMA, BPDM, HEMA, CQ, ñ- } \\
\text { dimethylaminobenzoic acid (co- } \\
\text { initiator), acetone, } 8.5 \% \text { glass fiber }\end{array}$ & Light-activated & 4.6 & $1,2,3,4,6,8$ \\
\hline Prime\&Bond NT (PB) & $\begin{array}{l}\text { Dentsply DeTrey GmbH, } \\
\text { Konstanz, Germany }\end{array}$ & $\begin{array}{l}\text { PENTA, UDMA, Resin R5-62-1, T- } \\
\text { Resin, D-Resin, Nanofillers, } \\
\text { Photoiniciators, Stabilizer, } \\
\text { Cetylamine hydrofluoride, Acetone }\end{array}$ & Light-activated & 2.6 & $1,2,3,5,7,9$ \\
\hline Bisfil 2B (B2B) & $\begin{array}{l}\text { Bisco, Schaumburg, } \\
\text { USA }\end{array}$ & $\begin{array}{l}\text { Bis-GMA, BPAEODMA (base only), } \\
\text { Glass Frit, TEGDMA, Silica, } \\
\text { Amorphous Silica }\end{array}$ & $\begin{array}{l}\text { C h e m i c a I I y } \\
\text { activated }\end{array}$ & - & 10 \\
\hline Filtek Z-100 (Z100) & $\begin{array}{l}\text { 3MESPE, } \\
\text { St. Paul, USA }\end{array}$ & $\begin{array}{l}\text { Silane treated ceramic, Bis-GMA, } \\
\text { TEGDMA, water }\end{array}$ & Light-activated & -- & 11 \\
\hline
\end{tabular}

*1 - dentin etching for $15 \mathrm{~s} ; 2$ - rinsing for $15 \mathrm{~s} ; 3$ - drying with gentle air-flow, leaving the surface moist and shiny; 4 (OS) - two coats of adhesive systems, brushed for $10 \mathrm{~s}$ each; 5 (PB) - one adhesive coat kept for $20 \mathrm{~s}$, brushed for $10 \mathrm{~s} ; 6$ (OS) - gentle air-drying; 7 (PB) - drying with gentle air-flow for $5 \mathrm{~s}$; 8 (OS) - light-activation (10 s, $\left.600 \mathrm{~mW} / \mathrm{cm}^{2}\right)$; 9 (PB) - lightactivation $\left(20 \mathrm{~s}, 600 \mathrm{~mW} / \mathrm{cm}^{2}\right) ; 10$ (B2B) - use of the necessary amount by turning syringe handle clockwise and mixing to a uniform paste (10-15 seconds); $11(\mathrm{Z100})$ - for $2 \mathrm{~mm}$ of resin, light-activation of $40 \mathrm{~s}$ duration time $\left(600 \mathrm{~mW}^{\mathrm{c}} \mathrm{cm}^{2}\right)$. 
$\mathrm{mm}^{2}$ of bonded area, measured with a digital caliper). Afterwards, these beams were attached to a custom-made testing device with cyanoacrylate gel. Such device consisted of an adapted caliper meant to ensure that pure tensile force was applied to the bond without any shear or torquing forces. The microtensile test $\left(1 \mathrm{~mm} \cdot \mathrm{min}^{-1}\right.$ crosshead speed, $10 \mathrm{kgfload}$ cell) was performed in a universal testing machine (Emic DL-1000, Emic, São José dos Pinhais, PR, Brazil).

\section{Statistical Analysis}

Each tooth was considered an experimental unit. The means of the different groups were calculated $(n=7)$ by using two-way analysis of variance and Tukey's multiplecomparison test $(p<0.05)$. Pre-test failures of the beams, that is, failures that occurred during handling were counted as "zero bonds" $(\mathrm{MPa}=0)$. The number of pre-testing failures is presented in Table 2. Statistical analysis was performed using Statistics 8.0 for Windows (Analytical Software Inc, Tallahassee, FL, USA).

\section{RESULTS}

According to the two-way analysis of variance, only the independent factor "adhesive" $\left(\mathrm{F}_{1,24}=29,24, \mathrm{p}=0.0001\right)$ and the "interaction factor" between the adhesive system and the composite $\left(\mathrm{F}_{1,24}=25,29, \mathrm{p}=0.0001\right)$ were statistically significant. Tukey's test $(\mathrm{p}<0.05)$ (Table 2$)$ showed that there was no statistically significant difference $(p>0.05)$ between the adhesives when they were combined to the lightactivated composite. When in combination with the chemically activated resin, One Step adhesive system had higher bond strengths than Prime \& Bond NT.

\section{DISCUSSION}

The incompatibility between one bottle total-etch systems and chemically activated resins has been primarily attributed to the acidic monomers from the oxygen inhibited layer in the adhesives that deactivate the basic amines used as catalysts in chemically activated and light-activated composites $^{20,22,23}$. Additionally, it has been found that simplified adhesive systems behave as permeable membranes that allow the passage of water coming from hydrated dentin after polymerization $^{5,23}$. Due to these two phenomena, the simplified adhesive systems present some disadvantages when compared to the multi-step etch-and-rinse and selfetch adhesives, such as poor bonding ${ }^{3,7,21}$ and reduced bond longevity ${ }^{24}$.

The hydrophilic monomer blends present in the adhesive composition are one of the causes of weak bonding. It has been shown that the water uptake responsible for the plasticization of the adhesive polymer networks happens on the first day of water storage and is proportional to the polarity of each material (presence of polar groups such as hydroxyl, carboxyl or phosphate) ${ }^{14}$. This factor may have accounted for the suboptimal bonding performance of Prime and Bond NT which contains high concentrations of phosphate from PENTA (Dipentaerythritol penta acrylate monophosphate) in the adhesive solution. Furthermore, according to Suh, et al..$^{21}$ (2003), the organophosphates can be much more aggressive than the carboxylate methacrylate monomers when inhibiting the polymerization of chemically activated resins. Therefore, the dentin bond strengths of Prime\&Bond NT combined to Bisfil 2B were reduced to a greater extent when compared to those of One Step adhered to the same resin.

Due to the high amount of hydrophilic monomers, totaland self-etch simplified adhesives also exhibit a great degree of permeability after polymerization. According to Tay, et al. ${ }^{23}$ (2004): "Single-bottle adhesives, because of their lack of a comparatively more hydrophobic bonding resin layer, behave as permeable membranes after polymerization. They permit the continuous transudation of dentinal fluid (...)". This means that the hydrophilic monomers within the oxygen inhibition layer develop an osmotic gradient and the water permeates the cured layer of these adhesives. Then, the water that migrates to the composite-adhesive interface is trapped in the form of water blisters in the adjacent hydrophobic resin layer ${ }^{7}$. This may interfere with coupling to light- ${ }^{7}$, chemically- and dual-activated composites ${ }^{23}$.

Although the light-activated resins undergo polymerization via generation of free radicals by tertiary amines, the rate and extent of polymerization of chemical or dual-activated resins tend to be more affected by the combination with simplified adhesives than the lightactivated ones. One possible explanation is that their initiation process occurs more rapidly and the acid-base reaction is quickly interrupted ${ }^{20,21}$. However, even adhesives like One Step that presented good compatibility with both chemically activated and light-activated resins in the present

TABLE 2- Bond strength means $(\mathrm{MPa}) \pm$ standard deviations of all groups. The number of pretest failures per group is presented in parenthesis

Composite Resin *

$\begin{array}{lll}\text { Adhesives } & \text { Z100 (light-activated) } & \text { B2B (chemically activated) } \\ \text { OS } & \text { Group 1 }(\mathrm{n}=7): 24.7 \pm 7.1^{\mathrm{a}}(10) & \text { Group 2 }(\mathrm{n}=7): 32.2 \pm 7.6^{\mathrm{a}}(8) \\ \text { PB NT } & \text { Group 3 }(\mathrm{n}=7): 23.8 \pm 5.7^{\mathrm{a}}(8) & \text { Group } 4(\mathrm{n}=7): 7.8 \pm 3.6^{\mathrm{b}}(32)\end{array}$

${ }^{*}$ Different superscript letters indicate statistically significant difference $(p<0.05)$. 
study were shown to be highly prone to absorbing water, which is thought to alter significantly its mechanical properties over time 5 .

A recent study ${ }^{3}$ revealed that the problems caused by the combination of one-bottle adhesives with chemically activated or dual-activated composite are basically $\mathrm{pH}-$ related. Because of that, and in spite of the reduced number of clinical steps, it is important that the professional be aware that the more acidic the adhesive, the lower the bond strengths to dentin. Recently, a practical way to minimize the effects of simplified adhesive systems has been proposed by Cadenaro, et al. ${ }^{4}$ (2005), who employed longer curing times than those recommended by the manufacturers. Another different approach to improve bonding is the use of an additional layer of hydrophobic adhesive on the polymerized adhesive layer ${ }^{12}$.

We are aware that the mode of failure analysis provides important information leading to predictions of clinical performance limits ${ }^{9}$, and that the lack of proper failure analysis is a limitation of our study. However, it can be assumed that, in the present study, most fractures occurred within the adhesion zone.

Our hypothesis was partially rejected. Although both adhesives presented comparable bond strengths when combined to light-activated resins, Prime\&Bond NT, the system presenting the lowest $\mathrm{pH}$, sustained dramatic reduction in dentin bonding when combined with a chemically activated resin. The greatest number of pre-test failures of beams in group 4 confirmed the detrimental effect of the adhesive with low $\mathrm{pH}$ on resin bond to dentin.

\section{CONCLUSION}

The adhesive with the lowest $\mathrm{pH}$ (Prime\&Bond NT) decreased the bond of the chemically activated (Bisfill 2B) composite to dentin. On the other hand, under the present conditions, the tested adhesives did not seem to affect the bond of light-activated composites to dentin significantly. Therefore, further studies in aging conditions are recommended.

\section{ACKNOWLEDGEMENTS}

The authors gratefully acknowledge 3M ESPE, Dentsply, and Bisco for the donation of all materials used in this study.

\section{REFERENCES}

1- Abu-Hanna A, Gordan VV. Evaluation of etching time on dentin bond strength using single bottle bonding systems. J Adhes Dent. 2004;6:105-10.

2- Buonocore MG. A simple method of increasing the adhesion of acrylic filling materials to enamel surfaces. J Dent Res. 1955;34;84953
3- Bolhuis PB, de Gee AJ, Kleverlaan CJ, El Zohairy AA, Feilzer AJ. Contraction stress and bond strength to dentin for compatible and incompatible combinations of bonding systems and chemical and light-cured core build-up resin composites. Dent Mater. 2006;22:22333

4- Cadenaro M, Antoniolli F, Sauro S, Tay FR, Di Lenarda R, Prati C, et al. Degree of conversion and permeability of dental adhesives. Eur J Oral Sci. 2005;113:525-30.

5- Carrilho MR, Tay FR, Pahsley DH, Tjaderhane 1, Carvalho RM. Mechanical stability of resin-dentin bond components. Dent Mater. 2005;21(3):232-41

6- Carvalho RM, Pegoraro TA, Tay FR, Pegoraro LF, Silva NRFA, Pashley DH. Adhesive permeability affects coupling of resin cements that utilize self-etching primers to dentine. J Dent. 2004;32:55-65.

7- Cheong C, King NM, Pashley DH, Ferrari M, Toledano M, Tay FR. Incompatibility of self-etch adhesives with chemical/dual-cured composites: two-step vs one-step systems. Oper Dent. 2003;28:74755

8- Degrange M, Roulet JF, editors. Minimally invasive restorations with bonding. Chicago: Quintessence; 1997.

9- Della Bona A, Anusavice KJ, Mecholsky JJ Jr. Failure analysis of resin composite bonded to ceramic. Dent Mater. 2003;19(8):693-9.

10 - Frankenberger R, Tay FR. Self-etch $v s$ etch-and-rinse adhesives: effect of thermo-mechanical fatigue loading on marginal quality of bonded resin composite restorations. Dent Mater. 2005;21:397-412.

11 - Kimyai S, Oskoee SS. Effect of 1-bottle light-cured adhesive acidity on microleakage of a self-cured composite. Oper Dent. 2006;31(6):694-8.

12 - King NM, Tay FR, Pashley DH, Hashimoto M, Ito S, Brackett WW, et al. Conversion of one-step to two-step self-etch adhesives for improved efficacy and extended application. Am J Dent. $2005 ; 18(2): 126-34$

13 - Lopes GC, Baratieri CM, Baratieri LN, Monteiro S Jr, Cardoso Vieira LC. Bonding to cervical sclerotic dentin: effect of acid etching time. J Adhes Dent. 2004;6:19-23.

14- Malacarne J, Carvalho RM, de Goes MF, Svizero N, Pashley DH, Tay FR, et al. Water sorption/solubility of dental adhesive resins. Dent Mater. 2006;22(10):973-80.

15- Mallmann A, Zovigo F, Soares M, Placido E, Ferrari M, Cardoso $\mathrm{PE}$. Microtensile dentin bond strength of self-etching and singlebottle adhesive systems in different cavity configurations. J Adhes Dent. 2003;5:121-7

16- Manhart J, Chen HY, Hamm G, Hickel R. Review of the clinical survival of direct and indirect restorations in posterior teeth of the permanent dentition. Oper Dent. 2004;29:481-508.

17- Nakabayashi N, Pashley DH. Hybridization of dental hard tissues. Tokyo: Quintessence; 2000.

18- Özok AR, Wu M-K, Gee AJ, Wesselink PR. Effect of dentin perfusion on the sealing ability and microtensile bond strengths of a total-etch versus an all-in-one adhesive. Dent Mater. 2004;20:47986.

19- Reis A, Loguercio AD, Carvalho RM, Grande RHM. Durability of resin dentin interfaces: effects of surface moisture and adhesive solvent component. Dent Mater. 2004;20:669-76. 
20 - Sanares AME, Itthagarun A, King NM, Tay FR, Pashley DH. Adverse surface interactions between one-bottle light-cured adhesives and chemical-cured composites. Dent Mater. 2001;17:542-56.

21 - Suh BI, Feng L, Pashley DH, Tay FR. Factors contributing to the incompatibility between simplified-step adhesives and chemicallycured or dual-cured composites. Part III. Effect of acidic resin monomers. J Adhes Dent. 2003;5:267-82.

22- Sun R, Suansuwan N, Kilpatrick N, Swain M. Characterization of tribochemically assisted bonding of composite resin to porcelain and metal. J Dent. 2000;28:441-5.

23 - Tay FR, Frankenberger R, Krejci I, Bouillaguet S, Pashley DH, Carvalho RM, et al. Single-bottle adhesives behave as permeable membranes after polymerization. I. In vivo evidence. J Dent. 2004;32:611-21.

24- Tay FR, Pashley DH. Dental adhesives of the future. J Adhes Dent. 2002;4:91-103.

25- Tay FR, Pashley DH, Yiu CK, Sanares AM, Wei SH. Factors contributing to the incompatibility between simplified-step adhesives and chemically-cured or dual-cured composites. Part I. Single-step self-etching adhesive. J Adhes Dent. 2003;5:27-40.

26- Tay FR, Pashley DH. Resin bonding to cervical sclerotic dentin: a review. J Dent. 2004;32:173-96.

27- Tay FR, Suh BI, Pashley DH, Prati C, Chuang SF, Li F. Factors contributing to the incompatibility between simplified-step adhesives and self-cured or dual-cured composites. Part II. Single-bottle, totaletch adhesive. J Adhes Dent. 2003;5:91-105. 